their geographical environment. In the East, they are farmers, and although many are very poor and all suffering from the effects of the economic depression, they differ little in condition from their white agricultural neighbours. In the northern hinterland they are hunters and trappers, and have suffered severely from white competition, and the same applies to some extent to the salmon fishing communities of the North-West coast; but the tribes of the Plains region (Alberta) who lost their livelihood with the extinction of the bison and became farmers and ranchers, have in many instances achieved prosperity in two generations. Finally, it may be added, it is possible for an Indian to become enfranchised on certain conditions, and to cease to rank legally as an Indian.

\section{Statistics of Unemployment}

THE report of the Ministry of Labour for 1936 directs attention to the exceptionally sharp rise in the numbers available for employment, which increased by 270,000 between July 1935 and July 1936, due mainly to a rise in the numbers of persons aged sixteen years resulting from the increased birth-rate in the immediate post-War years. Against this there was a large increase in the numbers in employment, which in December 1936 reached the highest level recorded since comparable statistics have been kept$11,132,000$ as against 10,629,000 in December 1935 . There was also a marked decrease in the numbers unemployed, the number of persons registering as unemployed at employment exchanges in December 1936 being $1,629,000$ as against $1,869,000$ in December 1935. This total includes 69,000 'casuals', 195,000 'temporarily stopped' and 82,000 'juveniles'. Analysis of the age distribution of unemployed men and women indicates that the problem of finding work for those in the older age groups is predominantly one affecting men, and that age proves a handicap to obtaining employment when younger persons are available. Severe unemployment continued in the coal mining industry, but on a lower level than in 1935. The position improved in all the metal trade groups; in the cotton industry, unemployment over the whole year was $15 \cdot 7$ per cent compared with $20 \cdot 9$ per cent in 1935. The position improved in the wool industry but remained severe in the jute industry and in textile finishing. Most other industries showed improvement.

There was a marked increase in the number of persons transferred from the depressed areas compared with previous years, and the proportionate increase in the number of families assisted to re-settle was even more notable. In view of the improved employment position, the whole country was thrown open in instructional centre recruitment, preference in allocation to centres being given to men from areas of heavy and prolonged unemployment. Some expansion in physical training is also reported. Juvenile employment conditions also improved, but there was no indication of a general revival of the apprenticeship system of engaging labour. Shortages of juvenile labour relate particularly to boys and girls in the 14-15 age group, and there was a widespread tendency to raise the starting wage of learners, particularly in unskilled and non-progressive employment. The policy of industrial transference of juveniles was continued in certain areas, as well as arrangements for vocational training and guidance and placing in employment. Reference is also made to progress in the decentralization of the work of the Ministry.

\section{Russian Trans-polar Flight}

THReE Soviet airmen, flying a single-engined 960 h.p. monoplane, "Ant 25", left Moscow on June 18 on a non-stop flight to San Francisco via the North Pole. According to the New York correspondent of The Times, they were compelled by poor visibility to land at Pierson Field, Vancouver Barracks, in the State of Washington, on June 20, when within six hundred miles of their goal. They had been in the air for 63 hours 17 minutes, and are stated to have passed near the Pole at an altitude of 14,000 ft. The three airmen, MM. Byelyakoff, Chkaloff and Baidukoff, have been decorated with the Soviet Order of Merit, and Mr. Roosevelt, in a congratulatory message to the Soviet Ambassador in the United States, referred to the flight as a "historic feat".

\section{Palæolithic Implements from Bombay}

Palfolithro implements from the island of Salsette, north of Bombay, of considerable importance as demonstrating for the first time the presence of a palæolithic culture in this region of India, have been placed on exhibition in the British Museum (Bloomsbury). This series of implements is the result of three years' excavations carried out by Lieut.-Commander Todd in Pleistocene deposits of alternating gravel and clay. The implements are of indurated shale and come from various levels of stratification. They include Lower, Middle and Upper Palæolithic types, which, however, differ considerably from previous palæolithic finds in India. The principal site is a quarry at Khandivli, situated some $100 \mathrm{ft}$. above sea-level near the foothills running up to the moun. tainous interior. Mesolithic implements occur as surface finds and also in the caves of Padan not far away, where they are associated with rock engravings. Diagrams of the geological conditions and photographs of the sites are also exhibited with the implements.

\section{Research on Diseases of Farm Animals}

AN extensive programme of investigation into the cause and prevention of disease in farm animals is being undertaken by the Animal Diseases Research Association at Moredun, near Edinburgh, under the direction of Dr. J. Russell Greig. It has for some time become apparent that the existing laboratories and animal accommodation at Moredun were in. sufficient for the Research Association's rapidly extending work, and Treasury sanction has recently been given to the recommendation of the Agricultural Research Council and the Department of Agriculture 
for Scotland that a grant not exceeding $£ 9,800$ should be made available (after taking into account any receipts from other sources) from the Development Fund to enable necessary building extensions to be undertaken. In view of the economic importance of grass sickness, it became clear to the Department of Agriculture for Scotland and the Agricultural Research Council that further extension and intensification of the research into the cause and prevention of this disease are necessary, and the Treasury has sanctioned an appropriation from the Development Fund to the Department of Agriculture for Scotland of a sum not exceeding $£ 3,200$ to meet the expenditure for extended work on this disease during the current financial year. Several contributions towards the cost of grass sickness investigation have been received from outside sources, notably that from the Racecourse Betting Control Board, which has granted $£ 1,000$ for the work at Moredun during 1937. While the cause of this fatal disease, which is reported to have killed 1,200-1,500 horses last summer and is by no means confined to Scotland, is suspected to be due to poisoning developed in the intestine by certain bacteria, taken in on grass or in some other way during feeding, this theory, though promising, is not yet proved. A large-scale vaccination trial, which is being made after careful preliminary experiments, is intended as a further test of this theory.

\section{General Science and Education for Citizenship}

Prof. Lancelot Hogren's address on "The Teaching of Science in the Education of the Citizen", delivered at a conference of higher education members of the National Union of Teachers on December 30 has now been made available in pamphlet form (London: National Union of Teachers). There is much that is controversial in the address, and the Union is careful to disclaim responsibility for its views and opinions; but its provocativeness is stimulating. It starts from the position that the social task of modern education is "to implement the age of plenty. To do it we have to make the record of scientific discovery an open Bible". In the teaching of science should be epitomized the drama of human achievement, and at each stage the question "Did this or that principle, this or that theory, help mankind to lift this or that stone in the building of the temple of plenty ?" will serve to discriminate between the essential and the non-essential constituents of any proposed curriculum and to reconcile the competing claims of specialists. But how about preparation for passing examinations designed by specialists without regard to the requirements of intelligent citizenship ? Will students taught on these principles be able to cope with them ? Will not those who are themselves destined to become specialists suffer ?

To these questions, Prof. Hogben gives answers based on his own teaching experience. The keen interest aroused by the approach to science as a social venture, and the framework of important facts and comprehensive principles provided by it make the memorizing of the less vital facts needed for passing examinations an easy matter and make a sound basis for later specialization. A fatal error in the teaching of science is the presentation of principles without regard to a sufficient background of relevant information. Prof. Hogben finds an illustration of this in present methods of teaching electricity and magnetism. He advocates a greatly extended use of films in the teaching of science. The cinema, he says, can bridge the gulf which now separates people who have a good visual imagination from those who have not.

\section{New Power Station on the Rhine}

IN the Escher-Wyss News of December, published by the well-known engineering works at Zurich, a complete description is given of the Albbruck-Dogern Power Station on the Rhine. The Rhine, which historically has played an outstanding part among the rivers of Europe, has gained appreciably in commercial importance during the last ten years. Formerly its importance depended on navigation, which gradually spread up the river from the Niederrhein to Basle, now a port handling more than $2 \cdot 2$ million tons annually. During the last ten years the utilization of the water-power has proceeded in the opposite direction from the Upper Rhine down the Rhine valley. The part of the river of greatest interest as regards power generation is that lying between the Lake of Constance and Strasbourg. This stretch extends about a hundred miles, and if we exclude the sudden drop at the Rhine Falls, the gradient is about 1 in a 1,000. There are now eight, including the latest, the Albbruck-Dogern, low head waterpower stations erected along this stretch of the Rhine.

For the complete utilization of the Rhine six further stations are projected. The installed output of all the stations together will amount to approximately one million horse power, and the average yearly generation of electricity will be about 5,000 million kilowatt hours. With the exception of the French station at Kembs, all the stations have Escher-Wyss water turbines. The new station at Albbruck-Dogern utilizes the flow from the head of the Rhine to the lower course of the Aare as far as the Klingnau power station. The water supplied by the head race has an average flow of 900 cubic metres per second. It is utilized in three vertical shaft turbines each of which is capable of developing 37,600 h.p. under a head of 11.5 metres and with a maximum flow of 290 cubic metres per second. The power station is at Albbruck and has a length of 87 metres and a breadth of $29 \cdot 3$ metres. The three sets, each consisting of a water turbine and an electric generator, are arranged in a row at right angles to the canal and 27 metres apart. After passing through a transformer the electric energy is transmitted at 104 kilovolts.

\section{Prepayment Electricity Metres}

THE prepayment meter is, in general, suitable for the user of electricity whose means are small. The advantages are that he pays in small amounts and 